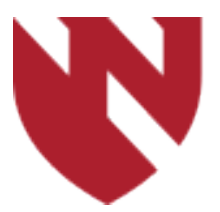

September 2020

\title{
CD24 Expression in Follicular Lymphoma: An Alternative B-Cell Marker in Therapy Selected, Recurrent Lymphoma
}

\author{
Katrina Lancaster-Shorts \\ University of Nebraska Medical Center \\ Samuel Pirruccello \\ University of Nebraska Medical Center
}

Tell us how you used this information in this short survey.

Follow this and additional works at: https://digitalcommons.unmc.edu/gmerj

Part of the Higher Education Commons, and the Medicine and Health Sciences Commons

\section{Recommended Citation}

Lancaster-Shorts, K., , Pirruccello, S. CD24 Expression in Follicular Lymphoma: An Alternative B-Cell Marker in Therapy Selected, Recurrent Lymphoma. Graduate Medical Education Research Journal. 2020 Sep 29; 2(1). https://digitalcommons.unmc.edu/gmerj/vol2/iss1/65 
CD24 Expression in Follicular Lymphoma: An Alternative B-Cell Marker in Therapy Selected, Recurrent Lymphoma

\section{Creative Commons License}

\section{(c) (1) $\Theta(9$}

This work is licensed under a Creative Commons Attribution-Noncommercial-No Derivative Works 4.0 License. 
quantity of MME prescribed at discharge correlated with higher pain scores at the first postoperative visit $(\mathrm{r}=0.25, \mathrm{p}=0.02)$ but not the second postoperative visit $(\mathrm{r}=0.17, \mathrm{p}=$ $0.15)$. There was no statistically significant association between MME prescribed and fracture characteristics or patient variables.

Conclusion: Postoperative opioid use correlated only with subjective, patient reported pain at the first postoperative visit, but did not correlate with injury mechanism, fracture characteristics, or patient variables.

https://doi.org/10.32873/unmc.dc.gmerj.2.1.063

\section{References}

1 Sairam Atluri, M.G.S., MD; Laxmaiah Manchikanti, MD, Assessment of the Trends of Medical Use and Misuse of Opioid Analgesics from 2004 to 2011. Pain Physician, 2014. 17: p. E119-E128.

2 Laxmaiah Manchikanti, M.A.S., BS, BA, Therapeutic Opioids: A Ten-Year Perspective on the Complexities and Complications the Escalating Use, Abuse, and Nonmedical Use of Opioids. Pain Physician, 2008. 11: p. S63-S88.
3 Boylan, M.R., et al., Patterns of Narcotic Prescribing by Orthopedic Surgeons for Medicare Patients. Am J Med Qual, 2018: p. 1062860618771190.

4 Attum, B., et al., Opioid Prescribing Practices by Orthopaedic Trauma Surgeons After Isolated Femur Fractures. J Orthop Trauma, 2018. 32(3): p. e106-e111.

5 Yu, N.N., et al., Persistence of Opioid Prescribing after a Forearm or Lower Leg Fracture. J Gen Intern Med, 2018. 33(3): p. 251-252.

6 Teng, Z., et al., Opioids contribute to fracture risk: a meta-analysis of 8 cohort studies. PLoS One, 2015. 10(6): p. e0128232.

7 Ping, F., et al., Opioids increase hip fracture risk: a meta-analysis. J Bone Miner Metab, 2017. 35(3): p. 289-297.

8 Buchheit, T., et al., Opioid exposure is associated with nonunion risk in a traumatically injured population: An inception cohort study. Injury, 2018.

9 Seth, P., et al., Quantifying the Epidemic of Prescription Opioid Overdose Deaths. Am J Public Health, 2018. 108(4): p. 500-502.

10 Bot, A.G., et al., Opioid use after fracture surgery correlates with pain intensity and satisfaction with pain relief. Clin Orthop Relat Res, 2014. 472(8): p. 2542-9.
11 Christensen, K.P., et al., The Effects of Anesthetic Technique on Postoperative Opioid Consumption in Ankle Fracture Surgery. Clin J Pain, 2016. 32(10): p. 870-4.

12 Finger, A., et al., Association Between Opioid Intake and Disability After Surgical Management of Ankle Fractures. J Am Acad Orthop Surg, 2017. 25(7): p. 519-526.

13 Helmerhorst, G.T.T., et al., Pain Relief After Operative Treatment of an Extremity Fracture: A Noninferiority Randomized Controlled Trial. J Bone Joint Surg Am, 2017. 99(22): p. 1908-1915.

14 McDonald, E., et al., Effect of Postoperative Ketorolac Administration on Bone Healing in Ankle Fracture Surgery. Foot Ankle Int, 2018: p. 1071100718782489.

15 Syed, U.A.M., et al., Neer Award 2018: the effect of preoperative education on opioid consumption in patients undergoing arthroscopic rotator cuff repair: a prospective, randomized clinical trial. $J$ Shoulder Elbow Surg, 2018. 27(6): p. 962-967.

\section{CD24 Expression in Follicular Lymphoma: An Alternative B-Cell Marker in Therapy Selected, Recurrent Lymphoma \\ Katrina Lancaster-Shorts ${ }^{1}$, Samuel Pirruccello'}

1 University of Nebraska Medical Center, Department of Pathology and Microbiology

Mentor: Samuel Pirruccello

Program: Pathology and Microbiology

Type: Original Research

Background: The rapidly expanding use of antigen targeted therapies, such as antiCD19, anti-CD20 and anti-CD22, in B-cell malignancies will require the application of additional B-cell-associated antigens in the assessment of residual disease. CD24 is a pan B-cell marker that undergoes significant surface density changes during normal maturation. In contrast to the loss of CD24 expression in normal follicles, we observed that follicle center derived lymphomas retain CD24 expression. Our aim was to determine the percentage of follicle center lymphomas with aberrant CD24 expression.

Methods: We reviewed 334 patients with a diagnosis of follicular lymphoma (FL; 228), large cell lymphoma of follicular origin (59) or B-cell lymphoma of follicular origin (47) by flow cytometry from October 2012 to August 2018. Cases without a confirmed tissue diagnosis of FL or diffuse large B-cell lymphoma (DLBCL) were excluded leaving 113 patients with FL, 38 patients with CD10positive DLBCL and 12 patients with mixed
FL/DLBCL. We analyzed the percentage of patients with CD24 positive lymphomas in each of the three diagnostic categories.

Results: We found that CD24 expression was retained in $89 \%$ of FLs $(101 / 113), 63 \%$ $(24 / 38)$ of DLBCLs and $42 \%(5 / 12)$ of mixed FL/DLBCL. Five cases of CD20 negative FL were $\mathrm{CD} 24$ positive.

Conclusion: Our results show the utility of aberrant CD24 expression in the identification of follicular lymphoma by flow cytometry.

https://doi.org/10.32873/unmc.dc.gmerj.2.1.065

\section{Performance of the Lymph2Cx Cell of Origin Classifier of Diffuse Large B-Cell Lymphoma in Comparison to Two Immunohistochemical Algorithms}

Katrina Lancaster-Shorts ${ }^{1}$, Ann Crowley ${ }^{1}$, Matthew Lunnin², Allison Cushman-Vokoun ${ }^{1}$, Jane Yuan¹, Catalina Amado ${ }^{1}$, Timothy Greiner ${ }^{1}$, Kai Fu¹, Hina Naushad Qureish ${ }^{1}$

${ }^{1}$ University of Nebraska Medical Center, Department of Pathology and Microbiology

${ }^{2}$ University of Nebraska Medical Center, Department of Internal Medicine, Division of Oncology and Hematology

Mentor: Naushad Qureishi

Program: Pathology and Microbiology

Type: Original Research

Background: Diffuse large B-cell lymphoma (DLBCL) is divided into cell-of-origin (COO) groups: germinal center B-cell (GCB), non-
GCB also known as activated B-cell (ABC) and intermediate/unclassified subgroups by mRNA gene expression profiling (mGEP). Immunohistochemical (IHC) classification algorithms, such as the Hans and Choi, were developed in lieu of mGEP on microarray, which could not analyze formalin fixed paraffin embedded (FFPE) tissue. The Nanostring Lymph2Cx assay is capable of
RNA gene expression profiling on FFPE tissue.

Methods: We studied 70 cases of DLBCL analyzed with the Lymph2Cx. Immunohistochemistry was performed on FFPE tissue sections using antibodies for CD10, BCL6, MUM1, GCET1 and FOXP1. Our aim was to determine the concordance 